\title{
病理組織検查により肺癌を疑われた 鼻咽腔惡性腫瘍に就て
}

\author{
*白岩俊雄 井上裕司 \\ 川目䍡太郎
}

鼻腔或は咽頭に原発した腫怚から頸部或は胸 腹部内臓等に其の転移が発見される事は，日常 屢々見聞するところであるが，逆に鼻腔や咽頭 に見出された腫愓が胸腹部臓器の腫愓の転移し たものではないかとの疑を持たれる例は比較的 稀とされて居る。剖検時に上気道の腫惶が，実 際は原発性肺癌からの転移であつたとの確証を 得た症例の報告も，本邦では数例を数えるに過 ぎない。

我々は最近䁷咽腔に発生した腫惖の試験切片 の組織学的所見が, 原発性肺癌に屢々見られる 組織像と酷似している為, 或いは肺癌の転移で はないかとの疑の下に，胸部所見の精査を行つ た興味ある症例を経験したので，之に就て報告 する。

\section{症例}

患者: 37才 男 会社員

初診 : 昭和 32 年 7 月 26 日

主訴 : 左舅閉及び血性鼻漏

現病の起始及び経過 :

約 3 年前より両側鼻閉が起り, 某医にて 2 年 前に右側， 1 年前に左側の夫反鼻咠手術を受け た。其後一旦鼻閉は消失したが約 3 ケ月より左 鼻閉が著明となる。 5 月10日某医科大学の耳鼻 科に受診, 試験切除の結果細網肉腫の疑が持た れたが，合大きくなつてから手術して取れば良 いと云はれ, その瀂加療されず患者は間も無く 転医した。其後鼻閉は次第に増強し，時に自発 性の血性鼻漏を見る様になり，近来は朝洗顔時 にも震々両側鼻出血を起す様になつた。最近は 急に起立した時に眩量感を起し易く, 頭重感, 後鼻漏も訴える様になつた。閉塞性鼻声が著明

\footnotetext{
* 東京医科大学耳鼻咽喉科学教室
}

で，会話が非常に困難になつたと云う。嗅覚障 碍は無い。

上記症状を苦にして新たに某耳鼻科医を訪れ た所，悪性腫愓の疑があるとして当科に紹介さ れた。

\section{既往歴 :}

幼時左中耳炎を経過し, 左側には難聴を訴党 る。聴力検查の結果, 平均 $50 \mathrm{db}$ の水平型の聴 力損失を認めた。

沿患者の云う所によれば，数年前より会社の 健康診断にて右肺浸潤の下に要注意と云はれて いる。

2 カ月前より下㢉が続き，会社の医師より大 腸カタルと云はれて治療され，現在は稍々軖快 している。

\section{現 症 :}

体格, 栄養中等度, 顔貌稍 貧血性。

前舅鏡検査で，鼻腔は正常で舅介の肥大る無 く中鼻道はよく開いている。，左側の鱟咽腔は表 面凹凹な平な腫瘍塊で充満し，稍々乳嘴状肉䒚 状を呈し，咽頭へ交通し得ず。'右側鼻咽腔から も同腫煊塊が見られるが，咽頭へ儘かに交通す る。

後鼻鏡検查では鼻咽腔に腫恒が広基性に浸潤 発育し，左後鼻孔を全く閉鎖し，右後鼻孔をる 半ば閉鎖している。易出血性。

左軟口蓋は上咽頭の腫啰塊によつて明瞭に口 腔内に膨隆し，左側口蓋扁桃，咽頭側索も正中 部へ向つて軽度の濔蔓性の腫脹を示し, 後口蓋 弓と共に特有の発赤と浸潤が見られる。

両鼓膜は強く涃濁し, 左は強く内陥して後上 部は肉芽状に腫脹, 穿孔は認めない。

内科的に，胸部は理学的に異常所見を認め ず, 左下腹部に系状腫瘤を触知し圧痛市り。 
気食会 報一9巻

肝・脾は触れず、リンパ節の腫脹る特に認めら れない。末梢血液及び尿に異常なく，血清梅毒 反応は陰性である。

\section{腫痼の病理組織学的所見：(第 1 図)}

鼻内より鉗除した甚だ硬い弾性の試験切片に よれば，一部扁平上皮に覆はれた結合織及びリ ンパ組織であり，一部に出血性の部分が見ら れ, 円形細胞の浸潤がある。又一部に腫瘍細胞 が認められる。この腫場細胞はリンパ細胞に似 ているが，核の濃染せる，又核の崩買せる末分 化の卵円形，紀鍾形，大小不同の細胞で巣状を なしている。

\section{第 1 図}

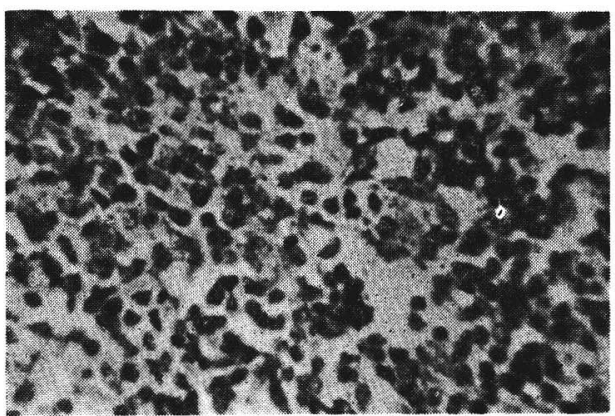

第 2 図

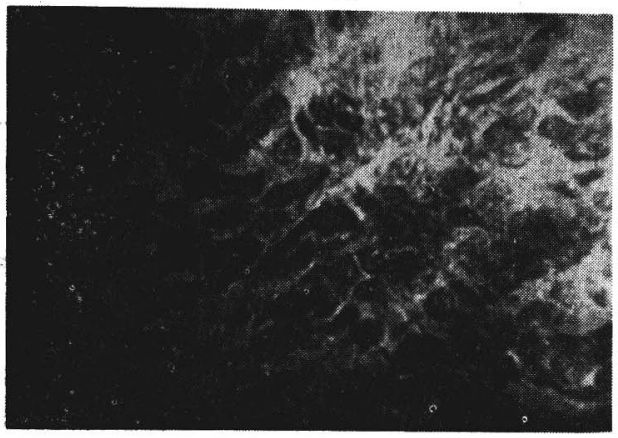

この所見より明らかに悪性度の高い癌腫と診 断されたが，我々がたまたま病理組織像に就て 意見を求めた米国の一部の病理学者は, 本組織 像が気管支性肺癌の未分化の癌腫, 所謂 oat cell type に酷似しているため, 最近同じ肺癌 で死亡した患者の腫犜の組織像と対照して，或 いは肺癌の転移せるものではないかとの推定診 断が下された。(第 2 図)

\section{治療経過：}

以上の様な組織所見を得たので，当院外科教 室へ胸部の精查を依頼すると共に，直らに該腫 瘴へ Cobalt 60 の照射を開始した。最初通院に て隔日に 60mc 7 回照射を行つたが，3回目頃 (180mc) より腫瘍は縮小し始め, 患者も亦発 語が㮐々楽になつて来た事を告げた。其後は入 院せ乙め, 計 $2,400 \mathrm{mc}$ の照射を行つたところ， 腫愓は僅かに咽頭側索と耳管開口部の腫脹を残 すのみとなり，自覚症状る全く消失したが，軟

第 3 図

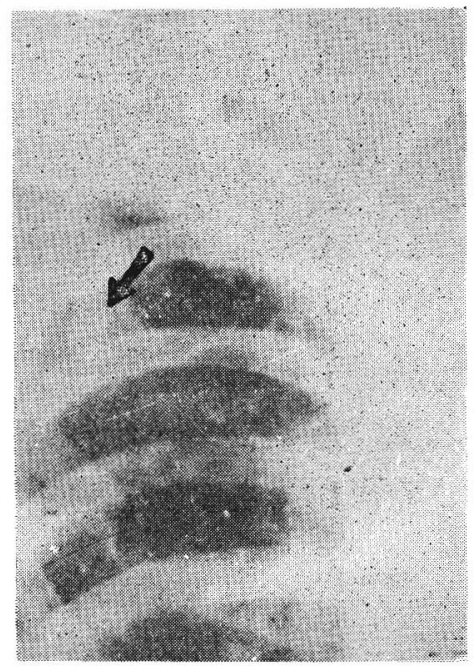

第 4 図

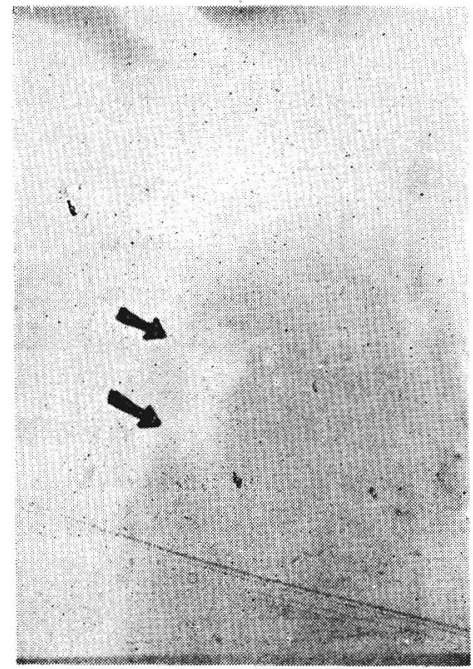


口蓋に Cobalt による杯爛を起し照射を一時中 断した。

外科に於ける胸部撮影の結果は，右第一及び 第二肋間に拇指頭大，辺縁の鮮鋭なる 2 箇の銭 型陰影が認められ，癌腫か或いは結核腫と推定 された。（第 3 及び第 4 図）喀痰の結核菌培養 は陰性。Papanicolaou 法も陰性。赤沈值は 1 時間時 $16 \mathrm{~mm}, 2$ 時間 $45 \mathrm{~mm}$, 気管支鏡検查, 気管支造影では特異な所見を認め得なかつた。 現在は鼻咽腔の腫瘍は全く完全に近く消腿した :が, 肺所見の方が向確診出来ぬ為, 引続き観察 中である。

Anderson によれば, 肺癌は組織学的に次の .4 型に大別される。即ち

1. Squamous cell type

2. Undifferentiated carcinoma (oat cell type)

3. Adenocarcinoma

4. Small round cell carcinoma (Lymphoid cell type)

で，本症例の鼻咽腔にその酷似した像の見られ た紡鍾形細胞癌を含めた Undifferentiated carcinoma が肺癌の半数近くを占めていると云は れる。

本症の診断に当つては従来は推定診断, 殊に X線診断がその大部分を占めていた。最近は 気管支鏡診断, 細胞学的診断等の確定診断も行 はれる様になつたが之とてもその確定率は低 く, 殊にX線像に銭型陰影の現れた場合は結核 腫との鑑別は極めて困難である。結核菌検査, 赤沈值, 試験的ストマイ治療等もなされるが, 之も補助的手段に過ざない。X線像を経過を追 つて観察する事も確定診断には不可欠の要点で あるが，腫愓の極く小さい場合は発育速度も緩
慢で, 直径が約 $5 \mathrm{~cm}$ を超えると急速に増大す ると云われ，又石灰化像を示して全く良性と考 へられていたものが，開胸によつて肺癌と確定 した例さえ多数ある。本症例も約 3 年前のX線 像と比較観察をされたが，特に銭型陰影の増大 は見られなかつた。

自覚的に本患者は時に喀痰の排出を見る程度 であるが，自覚症状の有無は術後の予後を左右 し，Peabody（1957）によれば治癒率は自覚症 状の有るもの $71 \%$ ，無自覚者 $13 \%$ と云はれ早期 の診断を要求される為, 我々も速かなる傕定診 断に鋭意努力中である。

尚我々が意見を求めた 米病理学者が，極めて最近 経験した肺癌の死亡例より作製した，所謂 oat cell type の組織像が，本例に如何に酷似しているかを附 図の写真で参照願いたい。

本症例については第 9 回気管食道科学会総会に於 て報告した。

\section{主要参考交献}

1) PATHOLOGY Edited by W. A. D. Anderson, M. A., M. D., F.A.C.P. The c.v. Mosby company. 1953

2) Text book of pathology by Robert Allan Moore W.B. Saunders company Philadelphia and London June, 1952

3) J. W. Peabody, Jr. et al., High Persentage of Malignancy in Solitary Pulmonary Nodule Med. Ann. District of Columbia, vol. 26, Jan., 1957

4) 篠原寿 癌 $37,244,1943$

5）竹田千里他 日耳鼻, 57, 433, 1954

6) 河原直次 . 日外会誌，56, 6, 1955

7）石川七郎 日外会誌，56，6，1955

8）篠井金吾, 日外会誌，56，6，1955 